\title{
Effect of grape seed extract (GSE) on functional activity and mineralization of OD-21 and MDPC-23 cell lines
}

Maria Carolina COELHO(a) iD Paula Katherine Vargas

SANCHEZ(a)

Roger Rodrigo FERNANDES(b) iD

Fernanda Panzeri Pires de

SOUZA(c) iD

Selma SIÉSSERE(a) iD

Karina Fittipaldi BOMBONATO-

PRADO $^{(a)}$ iD

(a) Universidade de São Paulo - USP, School of Dentistry of Ribeirão Preto, Department of Basic and Oral Biology, Ribeirão Preto, SP, Brazil.

(b) Universidade de São Paulo - USP, School of Dentistry of Ribeirão Preto, Department of Oral and Maxillofacial Surgery and Periodontology, Ribeirão Preto, SP, Brazil.

(c) Universidade de São Paulo - USP, School of Dentistry of Ribeirão Preto, Department of Dental Materials and Prosthesis, Ribeirão Preto, SP, Brazil.

Declaration of Interests: The authors certify that they have no commercial or associative interest that represents a conflict of interest in connection with the manuscript.

Corresponding Author:

Karina Fittipaldi Bombonato-Prado

E-mail: karina@forp.usp.br

https://doi.org/10.1590/1807-3107bor-2019.vol33.0013

Submitted: June 21, 2018

Accepted for publication: December 19, 2018

Last revision: January 14, 2019
Abstract: Recent studies on functional tissue regeneration have focused on substances that favor cell proliferation and differentiation, including the bioactive phenolic compounds present in grape seed extract (GSE). The aim of this investigation was to evaluate the stimulatory potential of GSE in the functional activity of undifferentiated pulp cells and odontoblast-like cells. OD-21 and MDPC-23 cell lines were cultivated in odontogenic medium until subconfluence, seeded in 24-well culture plates in a concentration of $2 \times 10^{4} /$ well and divided into: 1) OD-21 without GSE; 2) OD-21+10 $\mu \mathrm{g} / \mathrm{mL}$ of GSE; 3) MDPC-23 without GSE; 4) MDPC-23+10 $\mu \mathrm{g} / \mathrm{mL}$ of GSE. Cell proliferation, in situ detection of alkaline phosphatase (ALP) and total protein content were assessed after 3, 7 and 10 days, and mineralization was evaluated after 14 days. The data were analyzed by ANOVA statistical tests set at a $5 \%$ level of significance. Results revealed that cell proliferation increased after 10 days, and protein content, after 7 days of culture in MDPC-23 cells. In situ ALP staining intensity was higher in undifferentiated pulp cells and odontoblast-like cells after 7 and 10 days, respectively. A discrete increase in MDPC-23 mineralization after GSE treatment was observed despite OD-21 cells presenting a decrease in mineralized nodule deposits. Data suggest that GSE favors functional activity of differentiated cells more broadly than undifferentiated cells (OD-21). More studies with different concentrations of GSE must be conducted to confirm its benefits to cells regarding dentin regeneration.

Keywords: Grape Seed Extract; Odontoblast-Like Cells; Cell Line; Cell Proliferation.

\section{Introduction}

Pulpal wound healing, including reparative dentin formation, is a complex multifactorial process orchestrated by discrete but overlapping steps of migration, proliferation, and mineralization of pulp cells, ${ }^{1}$ formed by odontoblast-like cells presumably differentiated from DPSCs. ${ }^{2}$ In cases where this inherent ability of dentin-pulp complex regeneration 
cannot be achieved, several materials have been used to enhance this regenerative property, although some have been reported to exhibit cytotoxic effects, such as calcium hydroxide-based materials. ${ }^{3}$ Therefore, a possible alternative is to use extracts from plants containing polyphenols classified as proanthocyanidins (PACs), belonging to a category known as condensed tannins, which are highly hydroxylated structures capable of forming an insoluble complex with carbohydrates and proteins. ${ }^{4}$ The most abundant types of PACs are procyanidins, containing catechin and epicatechin subunits (Ferreira 2000). PACs are found in fruits, vegetables, nuts and seeds, mainly grape seeds; they increase collagen synthesis and are potent antimicrobial and antitumorigenic agents. ${ }^{5}$ Grape seed extract (GSE) has already demonstrated its biomedical potential for promoting greater dentin rigidity, based on the interaction of PACs with dentin collagen. ${ }^{6}$ Castellan et al. ${ }^{7}$ have reported that extracts rich in PACs are promising agents in the dental field, because they enhance the biomechanical properties and biostability of dentin. In addition, this extract has antioxidant, antitumor and antihyperglycemic properties, ${ }^{8}$ making it a compound with broad pharmacological and medicinal properties. ${ }^{5,9}$

The antioxidant activities of polyphenols may prevent several pathological conditions associated with the excessive production of reactive oxygen species (ROS) and reactive nitrogen species (RNS). These reactive species can attack key proteins, lipids and DNA, alter signal transduction pathways, destroy membranes and subcellular organelles, and subsequently cause apoptosis or cell death. ${ }^{10}$ Despite the positive benefits attributed to the polyphenols present in GSE, few studies have investigated its in vitro effects on the activity of cell mineralization from bone and on the pulp-dentin complex. Results have shown that PACs inhibit $\mathrm{H}_{2} \mathrm{O}_{2}$-promoted apoptosis in MC3T3-E1 cells, by enhancing the viability of MC3T3-E1 cells after $\mathrm{H}_{2} \mathrm{O}_{2}$ treatment, and reducing apoptotic cell numbers. ${ }^{11}$ Park et al. ${ }^{12}$ observed that in vivo administration of GSE improved the arthritic manifestations of collagen-induced arthritis (CIA) in mice, simultaneously suppressing in vitro osteoclast differentiation and promoting in vitro osteoblast differentiation. When investigating the early effects of GSE on cells derived from pulp tissue, Santos et al. ${ }^{13}$ observed that low concentrations of GSE were associated with an increase in cell viability, decreased production of nitric oxide, and increased synthesis of extracellular matrix by pulp cells from human third molars.

In light of the scant information in the literature about the effect of GSE on dental pulp cells with different levels of differentiation, we performed a 14-day comparative study between two cell lines developed by Hanks et al. as spontaneously immortalized cell lines derived from the dental papilla of the first molar of fetal mice. ${ }^{14}$ The cell lines consisted of undifferentiated pulp cells and odontoblast-like cells, i.e., OD-21 and MDPC-23. Therefore, the aim of this investigation was to evaluate the response of both cell lines in the presence of GSE, with the hypothesis that GSE might enhance their functional activity and mineralization.

\section{Methodology}

\section{Cell culture}

Two mouse cell lines were used: odontoblast-like cells (MDPC-23) and undifferentiated dental pulp cells (OD-21). ${ }^{7}$ The cells were cultured in Dulbecco's Modified Eagle's Medium (DMEM, Gibco BRL, Grand Island, NY, USA), supplemented with 10\% fetal bovine serum (Gibco, Grand Island, NY, USA), $200 \mathrm{mM}$ L-glutamine (Gibco), 50 units/mL penicillin (Gibco), and $50 \mu \mathrm{g} / \mathrm{mL}$ streptomycin (Gibco), in a humidified $5 \% \mathrm{CO}_{2}$ incubator at $37^{\circ} \mathrm{C}$. Both cell lines were cultured in odontogenic medium (OM), which contained $50 \mu \mathrm{g}$ of ascorbic acid to stimulate collagen and extracellular matrix formation, and $2 \mathrm{mM}$ betaglycerophosphate to promote the formation and mineralization of nodules in multilayers. Subconfluent cells were harvested after treatment with 1 mM EDTA (Gibco) and $0.25 \%$ trypsin, (Gibco), and subcultured in 24-well polystyrene plates (Falcon; Franklin Lakes, NJ, USA), at a density of $2 \times 10^{4}$ cells/well $(n=5)$, with or without $10 \mu \mathrm{g} / \mathrm{mL}$ (concentration based on the report by Fujishita et al. ${ }^{10}$ ) of MegaNatural ${ }^{\circledR}$-BP GSE (Polyphenolics Inc., Madera, USA). This extract presents $93.9 \mathrm{~g}$ out of $100 \mathrm{~g}$ of phenolic compounds, 
composed mainly of oligomers and polymers from catechins and epicatechins. ${ }^{15}$

\section{Cell proliferation}

Cell proliferation was assessed by the MTT colorimetric assay [3-(4,5-dimethylthiazol-2-yl)-2,5diphenyltetrazolium bromide] (Sigma), after 3, 7 and 10 days of culture. The culture medium was removed, and the cells were incubated with OM + MTT 10\% solution for 4 hours at $37^{\circ} \mathrm{C}$, in a humidified atmosphere containing 5\% $\mathrm{CO}_{2}$ and $95 \%$ atmospheric air. After this period, the culture medium was removed from the wells, and $1 \mathrm{~mL}$ of acid isopropanol solution (Merck, Darmstadt, Germany) was added to each well under agitation for 5 minutes to obtain complete solubilization. Aliquots of $150 \mu \mathrm{L}$ were transferred to a 96-well plate for spectrophotometric reading ( $\mu$ Quant, Bio-tek Instruments Inc., Winooski, USA) at a wavelength of $570 \mathrm{~nm}$.

\section{Total protein content}

Total protein content was determined at 3, 7 and 10 days of the experiment. Briefly, proteins were extracted from each well with $0.1 \%$ sodium lauryl sulfate (Sigma-Aldrich) for $30 \mathrm{~min}$, and mixed 1:1 with Lowry solution (Sigma-Aldrich) for $20 \mathrm{~min}$ at room temperature (RT). The extract was diluted in Folin \& Ciocalteu's phenol reagent (Sigma-Aldrich) for $30 \mathrm{~min}$ at RT. Absorbance was measured at $680 \mathrm{~nm}$ using a spectrophotometer (Cecil CE3021, Cambridge, UK).

\section{In situ detection of alkaline phosphatase}

Detection of in situ alkaline phosphatase (ALP) was performed at 3, 7 and 10 days. After removal of the culture medium, the wells were washed twice with PBS at $37^{\circ} \mathrm{C}$. Then $320 \mathrm{mg}$ of Triz reagent (Sigma) was dissolved in $20 \mathrm{~mL}$ of deionized water, and both 7 mg of Fast Red reagent (Sigma) and $8 \mathrm{mg}$ of Naphthol (Sigma) diluted in $2 \mathrm{~mL}$ of dimethylformamide (Merck) were added. Each well received $1 \mathrm{~mL}$ of this working solution, and the plate was taken into the incubator in a humidified atmosphere with $5 \% \mathrm{CO}_{2}$ at $37^{\circ} \mathrm{C}$ for 30 minutes. After this time, the solution was removed from the wells, and the plate was left to dry at RT for further photographic documentation.
The colored images were converted into binary images using Image J software, and then converted to grayscale, to allow the pixels to be counted for a quantitative analysis.

\section{Mineralized matrix formation}

The mineralized matrix was evaluated after 14 days. After removal of the culture medium, the wells were washed three times with PBS (Gibco) at $37^{\circ} \mathrm{C}, 2 \mathrm{~mL}$ of formalin $10 \%$ was added for fixation, and the wells were stored for 24 hours at $4^{\circ} \mathrm{C}$. Then the formalin was removed, and wells were dehydrated with increasing sets of alcohol concentrations $\left(30^{\circ}, 50^{\circ}, 70^{\circ}\right.$ and $\left.100^{\circ}\right)$ at one-hour intervals. After drying, the wells were stained with alizarin red 2\% pH 4.2 (Sigma) for 10 minutes, and the calcium-rich mineralization areas were revealed by red staining. A $280 \mu \mathrm{L}$ aliquot of acetic acid 10\% (Labsynth, Lab Ltda, Diadema, Brazil) was added to each well for quantification, and the plates were left under agitation for 30 minutes. The cell layer was scraped with a pipette; the solution was transferred to $1.5 \mathrm{~mL}$ Eppendorf tubes, heated for 10 minutes at $85^{\circ} \mathrm{C}$ and cooled on ice for 5 minutes. The tubes were centrifuged at 13,000 rpm for 20 minutes. An aliquot of $150 \mu \mathrm{L}$ of the supernatant was transferred to a 96-well plate, and $40 \mu \mathrm{L}$ of ammonium hydroxide 10\% (Quimibras, Rio de Janeiro, Brazil) was added. The reading was performed in a spectrophotometer (Bio-Tek), at a wavelength of $405 \mathrm{~nm} .^{16}$

\section{Statistical analysis}

Statistical analysis was performed using Graph Pad Prism 6.0e ${ }^{\circledR}$ (Graph Pad Software Inc., San Diego, USA). The data were expressed as mean \pm standard deviation, and analyzed by means of analysis of variance (ANOVA), followed by Tukey's multiple comparison test with a level of significance set at $5 \%(\mathrm{p} \leq 0.05)$.

\section{Results}

\section{Cell proliferation}

Figure 1 shows that proliferation of both cell lines increased significantly seven days after culture, followed by a decrease on the tenth day $(p<0.0001)$. 
A

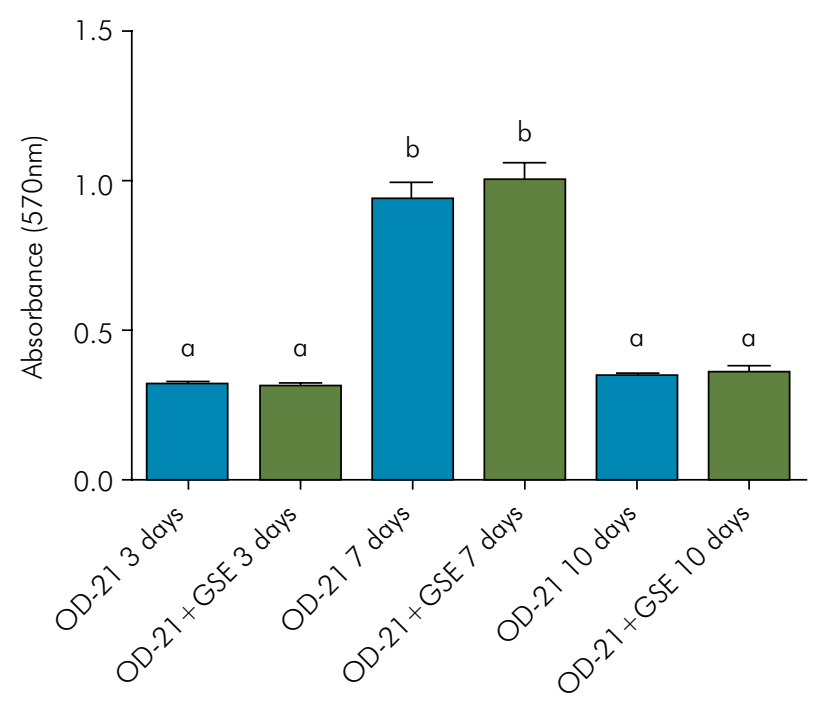

B

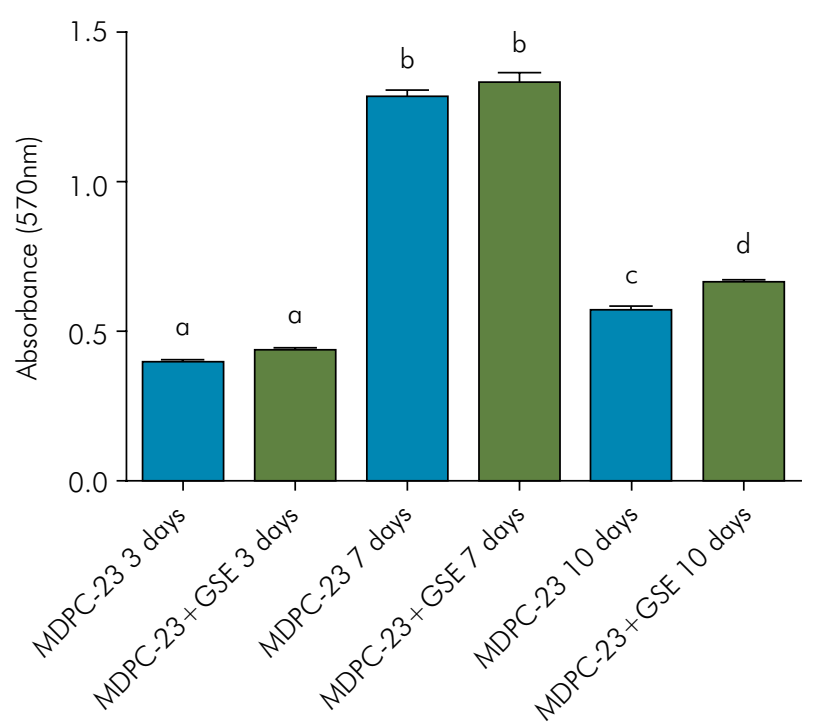

Figure 1. OD-21 (A) and MDPC-23 (B) cell proliferation by MTT assay after 3, 7 and 10 days. Different letters mean statistical difference set at $5 \%$ (ANOVA).

A

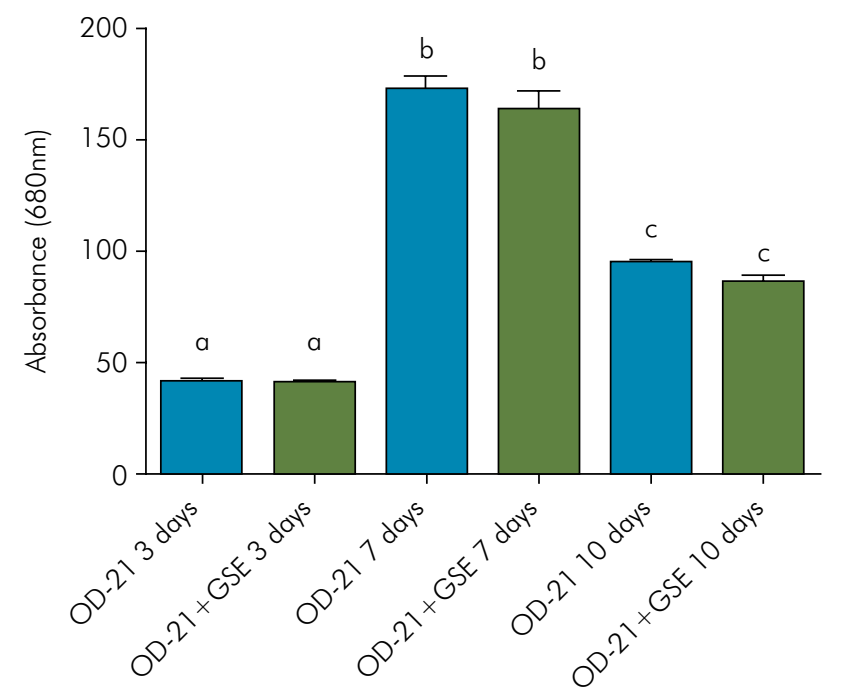

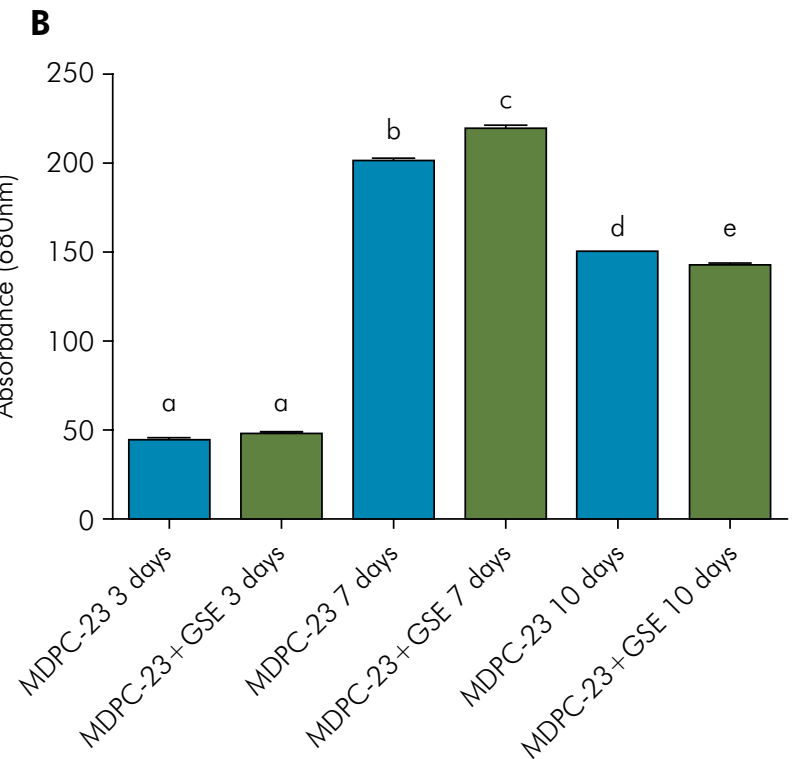

Figure 2. OD-21 (A) and MDPC-23(B) total protein content after 3, 7 and 10 days. Different letters mean statistical difference set at $5 \%(A N O V A)$.

Undifferentiated pulp cells showed no difference in proliferation in the presence of GSE, in any of the periods studied. Nevertheless, MDPC-23 cells revealed a significant increase in proliferation after 10 days of culture with GSE $(\mathrm{p}<0.0001)$.

\section{Protein content}

Protein content was significantly higher after seven days of culture for both cell lines, with or without GSE treatment, compared with the other experimental periods $(p<0.0001)$. Figure 2 shows that GSE did not 
A
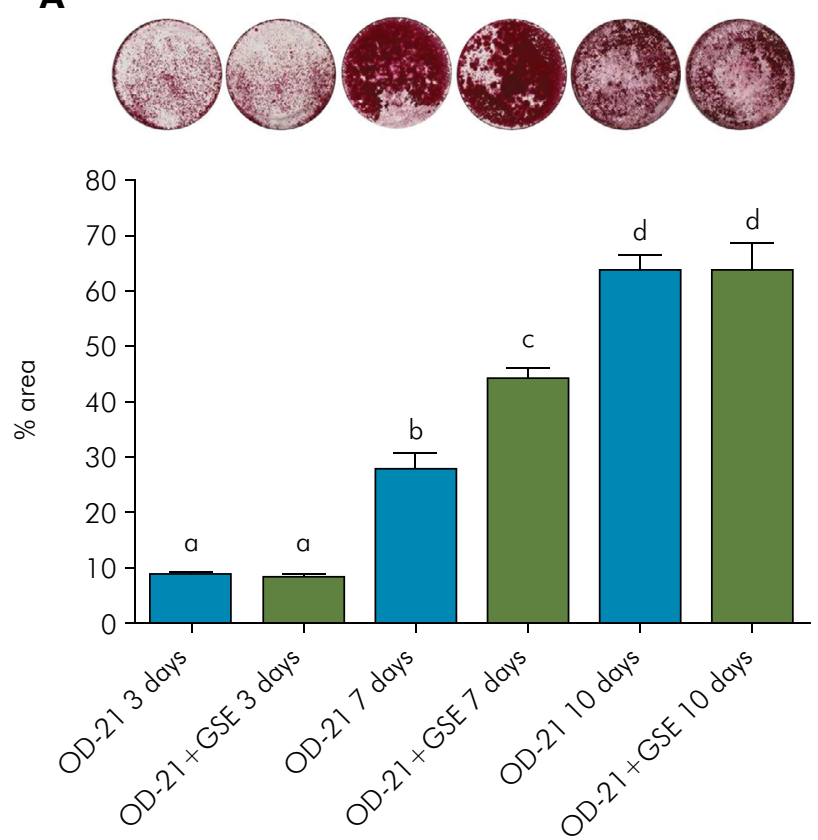

B
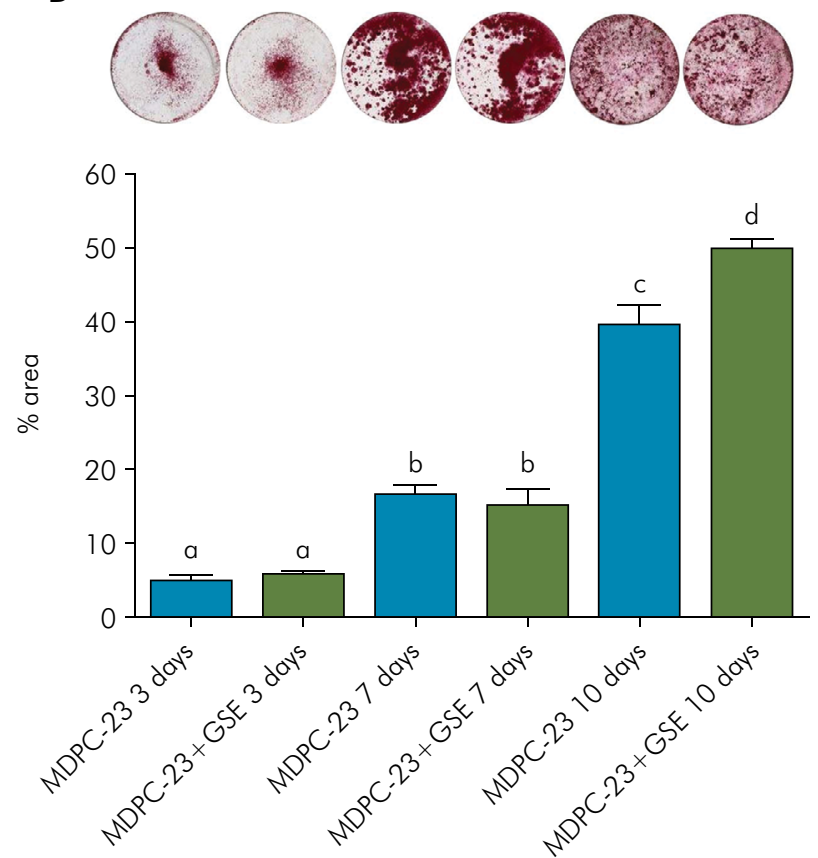

Figure 3. OD-21 (A) and MDPC-23(B) quantitative and qualitative alkaline phosphatase (ALP) in situ detection after 3, 7 and 10 days. Different letters mean statistical difference set at 5\% (ANOVA).

interfere in protein synthesis in OD-21 cells over the experimental period, and no statistical differences were detected. Odontoblast-like cells, however, showed a significant increase in total protein synthesis after seven days of culture, followed by a decrease after 10 days $(\mathrm{p}<0.001)$.

\section{In situ ALP defection}

In Figure 3, the detection of ALP by means of in situ staining revealed that ALP was deposited continuously over the experimental period, with significantly higher detection after 7 and 10 days of culture, in both investigated cell lines. The presence of GSE significantly increased ALP detection in OD-21 cells on the seventh day of the experiment, whereas the increase in odontoblast-like cells was observed after 10 days of culture $(\mathrm{p}<0.001)$.

\section{Mineralization}

Deposition of mineralized nodules was detected and quantified, as observed in Figure 4. Despite the higher ALP deposition observed by in situ staining over the experimental periods evaluated, there was no significant increase in mineralization in either
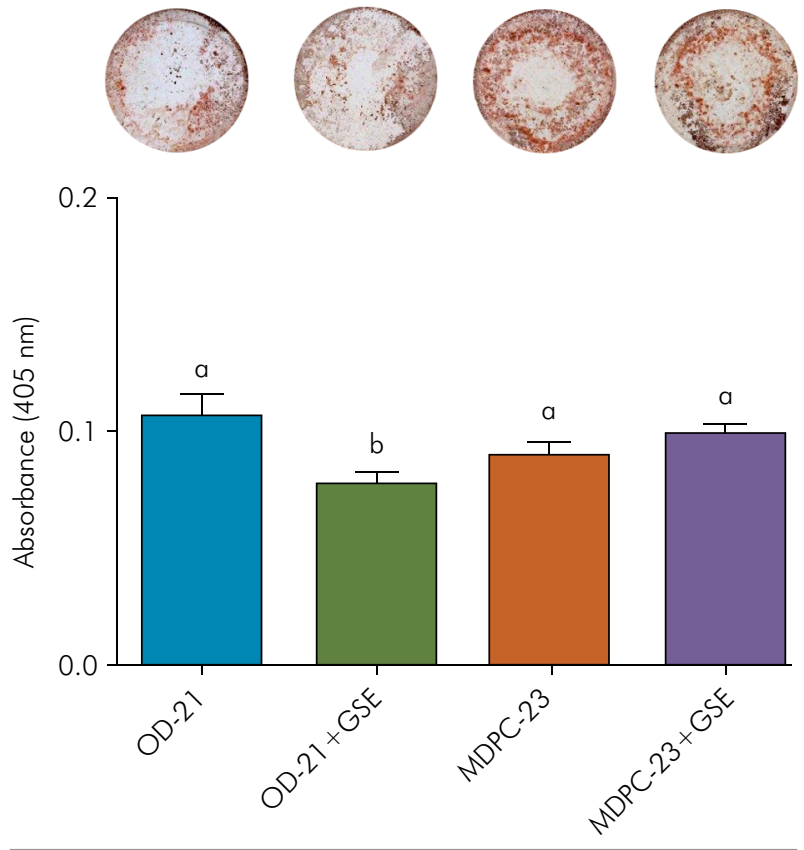

Figure 4. Detection and quantification of OD-21 and MDPC-23 mineralization after 14 days. Different letters mean statistical difference set at 5\% (ANOVA).

of the investigated cell lines. In fact, a significant decrease was noted in OD-21 mineralization after GSE 
treatment, whereas a subtle, insignificant increase was revealed for MDPC-23.

\section{Discussion}

Recent research has focused increasingly on natural substances extracted from plants for use as therapeutic agents. ${ }^{17}$ GSE is composed essentially of PACs (proanthocyanidins), and is best known for its antioxidant action, up to five times more effective than vitamin $\mathrm{C}^{18}$ It is a proven nontoxic substance that is safe for ingestion. ${ }^{19}$

PACs are phenolic compounds with the potential for generating a nonbiodegradable collagen matrix. ${ }^{20}$ Their effect has been studied and confirmed in restorative dentistry, with positive results in the treatment of carious lesions, ${ }^{21}$ in the mechanism of dentin-resin adhesion ${ }^{22}$ and in the resistance to demineralized dentin biodegradation. ${ }^{23}$ Investigations into the effects of GSE in its functional activity of mineralizing cells are still incipient. Our results add new information to the literature, by shedding light on the influence of PACs in the metabolism of undifferentiated pulp cells and odontoblasts.

The presence of GSE in the culture medium did not inhibit the majority of cell activities, as measured by the parameters evaluated. Proliferation of OD-21 cells was similar in the presence or absence of GSE. Nevertheless, MDPC-23 cells showed an increase in proliferation in late culture periods. The concentration of $10 \mu \mathrm{g} / \mathrm{mL}$ of GSE selected for this investigation is considered low, and most articles related to this topic indicate that only high concentrations of GSE are strong enough to inhibit proliferation, especially of tumor cells. Earlier reports suggested that the antiproliferative effect of GSE in high concentrations could be attributed to the presence of gallic acid and B2-3,3'-di-O-galate in the extract. ${ }^{24,25}$ Yen et al. ${ }^{26}$ demonstrated that a decrease in cell proliferation occurs with high concentrations of GSE (50-400 $\mu \mathrm{g} / \mathrm{mL}$ ), and not with low concentrations (1-10 $\mu \mathrm{g} / \mathrm{mL})$, mainly because of ROS generation and mitochondrial depolarization.

The influence of protein synthesis on the dentin matrix structure is essential, mainly regarding collagen production by odontoblastic cells and their progenitors.
According to Breschi et al., ${ }^{27}$ the collagen from mature dentin cannot be remodeled and is not easily degraded. The formation of covalent intermolecular crosslinking is the final modification in collagen biosynthesis, and is critical for collagen stability. ${ }^{28}$ Dentin contains the collagen with the highest number of intermolecular crosslinks in the human body. Crosslinking is a property of collagen molecules that makes them more closely linked and better structured, and influences the mechanical properties of collagen fibrils, thus enhancing resistance and stabilization. ${ }^{29}$ Thus, breaking these links may result in severe tissue dysfunction. ${ }^{30}$ Phansalkar et al. ${ }^{6}$ stated that the PACs in GSE have a great potential as dentin biomodifiers, providing rigidity and stability to the dentin structure. PACs intermediate and benefit collagen crosslinking, by enhancing collagen properties with their composition and chemical structure. ${ }^{31}$ Protein synthesis in both of the cell lines investigated was not inhibited by GSE; instead, it increased in MDPC-23 cells, suggesting a positive effect on the synthesis of proteins important to extracellular matrix formation.

ALP plays a special role in the mineralization of bone and dentin matrix, by exhibiting gradual increase at the beginning of odontoblastic differentiation. ${ }^{32}$ In our study, GSE did not interfere in the secretion of ALP in either cell line investigated, and could be evidenced by staining in culture wells. In addition, the extract increased ALP deposition significantly in both cell lines. Our results differ from those of Santos et al. ${ }^{13}$, who evaluated the culture of human pulp cells from third molars, and observed no difference in ALP production between the control and the group exposed to the extract. According to these authors, this could be explained by the contact time with the grape extract made only on the last day of differentiation. In contrast, we exposed the cells throughout the experimental periods, suggesting that ALP activity underwent stimulation. In addition, experimental evidence indicates direct stimulatory action in mineralization after administration of other polyphenols, like resveratrol. This is mainly attributed to an increase in ALP activity in osteoblasts, suggesting a behavior similar to estrogen. ${ }^{33}$ 
In the present study, mineralized nodule formation decreased in OD-21 cells and showed a discrete increase in MDPC-23 cells, despite an increase in ALP activity. The different behavior in mineralization might be explained by the differential gene expression that occurs in both studied cell lines, as evaluated in an earlier report of our research group. ${ }^{34}$ The report shows great similarities in the expression of genes associated with odontogenesis, such as I110, Traf6, Lef1 and Hspa8, as well as differences in induction and repression of genes such as Jak2 and Fas, both associated with proliferation, differentiation and apoptosis, during the process of odontogenesis. Thus, further studies of GSE effects on gene expression may be important toward obtaining a better understand of both the role of this extract in cell metabolism and the activity of cells at different levels of differentiation. Nevertheless, the data obtained are promising and suggest that advances can be achieved with further studies performed with different GSE concentrations involving different parameters and in vivo evaluations, with the application of GSE in deep cavities, and with direct association to pulp teeth, since low concentrations of the extract did not inhibit the functional activity of cells associated with dentinogenesis.

\section{Acknowledgements}

The authors would like to thank the São Paulo Research Foundation (Fapesp, Brazil) for its funding (process number 2016/18678-1) and the National Institute of Science and Technology - Translational Medicine, Brazil. The authors also wish to express their gratitude to Dr. Jacques Eduardo Nör (University of Michigan, Ann Arbor, USA) for providing the cell lines to perform the experiments.

\section{References}

1. Goldberg M. Pulp healing and regeneration: more questions than answers. Adv Dent Res. 2011 Jul;23(3):270-4. https://doi.org/10.1177/0022034511405385

2. Song M, Yu B, Kim S, Hayashi M, Smith C, Sohn S, et al. Clinical and molecular perspectives of reparative dentin formation: lessons learned from pulp-capping materials and the emerging roles of calcium. Dent Clin North Am. 2017 Jan;61(1):93-110. https://doi.org/10.1016/i.cden.2016.08.008

3. Poggio C, Ceci M, Dagna A, Beltrami R, Colombo M, Chiesa M. In vitro cytotoxicity evaluation of different pulp capping materials: a comparative study. Arh Hig Rada Toksikol. 2015 Sep;66(3):181-8. https://doi.org/10.1515/aiht-2015-66-2589

4. Bedran-Russo AK, Pauli GF, Chen SN, McAlpine J, Castellan CS, Phansalkar RS, et al. Dentin biomodification: strategies, renewable resources and clinical applications. Dent Mater. 2014 Jan;30(1):62-76. https://doi.org/10.1016/i.dental.2013.10.012

5. Li WG, Zhang XY, Wu YJ, Tian X. Anti-inflammatory effect and mechanism of proanthocyanidins from grape seeds. Acta Pharmacol Sin. 2001 Dec;22(12):1117-20.

6. Phansalkar RS, Nam JW, Chen SN, McAlpine JB, Napolitano JG, Leme A, et al. A galloylated dimeric proanthocyanidin from grape seed exhibits dentin biomodification potential. Fitoterapia. 2015 Mar;101:169-78. https://doi.org/10.1016/j.fitote.2014.12.006

7. Castellan CS, Bedran-Russo AK, Karol S, Pereira PN. Long-term stability of dentin matrix following treatment with various natural collagen cross-linkers. J Mech Behav Biomed Mater. 2011 Oct;4(7):1343-50. https://doi.org/10.1016/i.jmbbm.2011.05.003

8. Bao L, Zhang Z, Dai X, Ding Y, Jiang Y, Li Y, et al. Effects of grape seed proanthocyanidin extract on renal injury in type 2 diabetic rats. Mol Med Rep. 2015 Jan;11(1):645-52. https://doi.org/10.3892/mmr.2014.2768

9. Pérez C, Ruiz del Castillo ML, Gil C, Blanch GP, Flores G. Supercritical fluid extraction of grape seeds: extract chemical composition, antioxidant activity and inhibition of nitrite production in LPS-stimulated Raw 264.7 cells. Food Funct. 2015 Aug;6(8):2607-13. https://doi.org/10.1039/C5FO00325C

10. Fujishita K, Ozawa T, Shibata K, Tanabe S, Sato Y, Hisamoto M, et al. Grape seed extract acting on astrocytes reveals neuronal protection against oxidative stress via interleukin-6-mediated mechanisms. Cell Mol Neurobiol. 2009 Dec;29(8):1121-9. https://doi.org/10.1007/s10571-009-9403-5

11. Zhang Z, Zheng L, Zhao Z, Shi J, Wang X, Huang J. Grape seed proanthocyanidins inhibit H2O2-induced osteoblastic МС3Т3-E1 cell apoptosis via ameliorating H2O2-induced mitochondrial dysfunction. J Toxicol Sci. 2014;39(5):803-13. https://doi.org/10.2131/its.39.803 
Effect of grape seed extract (GSE) on functional activity and mineralization of OD-21 and MDPC-23 cell lines

12. Park JS, Park MK, Oh HJ, Woo YJ, Lim MA, Lee JH, et al. Grape-seed proanthocyanidin extract as suppressors of bone destruction in inflammatory autoimmune arthritis. PLoS One. 2012;7(12):e51377. https://doi.org/10.1371/journal.pone.0051377

13. Santos AF, Pacheco JM, Silva PA, Bedran-Russo AK, Rezende TM, Pereira PN, et al. Direct and transdentinal biostimulatory effects of grape seed extract rich in proanthocyanidin on pulp cells. Int Endod J. 2018 Sep. https://doi.org/10.1111/iej.13019

14. Hanks CT, Fang D, Sun Z, Edwards CA, Butler WT. Dentin-specific proteins in MDPC-23 cell line. Eur J Oral Sci. 1998 Jan;106(S1 Suppl 1):260-6. https://doi.org/10.1111/j.1600-0722.1998.tb02185.x

15. Edirisinghe I, Burton-Freeman B, Tissa Kappagoda C. Mechanism of the endothelium-dependent relaxation evoked by a grape seed extract. Clin Sci (Lond). 2008 Feb;114(4):331-7. https://doi.org/10.1042/CS20070264

16. Gregory CA, Gunn WG, Peister A, Prockop DJ. An Alizarin red-based assay of mineralization by adherent cells in culture: comparison with cetylpyridinium chloride extraction. Anal Biochem. 2004 Jun;329(1):77-84. https://doi.org/10.1016/j.ab.2004.02.002

17. Ferrazzano GF, Amato I, Ingenito A, Zarrelli A, Pinto G, Pollio A. Plant polyphenols and their anti-cariogenic properties: a review. Molecules. 2011 Feb;16(2):1486-507. https://doi.org/10.3390/molecules16021486

18. Bagchi D, Garg A, Krohn RL, Bagchi M, Tran MX, Stohs SJ. Oxygen free radical scavenging abilities of vitamins $C$ and E, and a grape seed proanthocyanidin extract in vitro. Res Commun Mol Pathol Pharmacol. 1997 Feb;95(2):179-89.

19. Song Q, Shi Z, Bi W, Liu R, Zhang C, Wang K, et al. Beneficial effect of grape seed proanthocyanidin extract in rabbits with steroid-induced osteonecrosis via protecting against oxidative stress and apoptosis. J Orthop Sci. 2015 Jan;20(1):196-204. https://doi.org/10.1007/s00776-014-0654-8

20. Kim SJ, Lim MH, Chun IK, Won YH. Effects of flavonoids of Ginkgo biloba on proliferation of human skin fibroblast. Skin Pharmacol. 1997;10(4):200-5. https://doi.org/10.1159/000211505 PMID:9413894

21. Silva AP, Gonçalves RS, Borges AF, Bedran-Russo AK, Shinohara MS. Effectiveness of plant-derived proanthocyanidins on demineralization on enamel and dentin under artificial cariogenic challenge. J Appl Oral Sci. 2015 May-Jun;23(3):302-9. https://doi.org/10.1590/1678-775720140304

22. Leme-Kraus AA, Aydin B, Vidal CM, Phansalkar RM, Nam JW, McAlpine J, et al. Biostability of the Proanthocyanidins-Dentin Complex and Adhesion Studies. J Dent Res. 2017 Apr;96(4):406-12. https://doi.org/10.1177/0022034516680586

23. Fawzy AS, Priyadarshini BM, Selvan ST, Lu TB, Neo J. Proanthocyanidins-loaded nanoparticles enhance dentin degradation resistance. J Dent Res. 2017 Jul;96(7):780-9. https://doi.org/10.1177/0022034517691757

24. Veluri R, Singh RP, Liu Z, Thompson JA, Agarwal R, Agarwal C. Fractionation of grape seed extract and identification of gallic acid as one of the major active constituents causing growth inhibition and apoptotic death of DU145 human prostate carcinoma cells. Carcinogenesis. 2006 Jul;27(7):1445-53. https://doi.org/10.1093/carcin/bgi347

25. Agarwal C, Veluri R, Kaur M, Chou SC, Thompson JA, Agarwal R. Fractionation of high molecular weight tannins in grape seed extract and identification of procyanidin B2-3,3'-di-O-gallate as a major active constituent causing growth inhibition and apoptotic death of DU145 human prostate carcinoma cells. Carcinogenesis. 2007 Jul;28(7):1478-84. https://doi.org/10.1093/carcin/bgm045

26. Yen CY, Hou MF, Yang ZW, Tang JY, Li KT, Huang HW, et al. Concentration effects of grape seed extracts in anti-oral cancer cells involving differential apoptosis, oxidative stress, and DNA damage. BMC Complement Altern Med. 2015 Mar;15(1):94. https://doi.org/10.1186/s12906-015-0621-8

27. Breschi L, Maravic T, Cunha SR, Comba A, Cadenaro M, Tjäderhane L, et al. Dentin bonding systems: from dentin collagen structure to bond preservation and clinical applications. Dent Mater. 2018 Jan;34(1):78-96. https://doi.org/10.1016/i.dental.2017.11.005

28. Yamauchi M, Shiiba M. Lysine hydroxylation and cross-linking of collagen. Methods Mol Biol. 2008;446:95-108. https://doi.org/10.1007/978-1-60327-084-7_7

29. Castellan CS, Bedran-Russo AK, Antunes A, Pereira PN. Effect of dentin biomodification using naturally derived collagen cross-linkers: one-year bond strength study. Int J Dent. 2013;2013:918010. https://doi.org/10.1155/2013/918010

30. Miura J, Nishikawa K, Kubo M, Fukushima S, Hashimoto M, Takeshige F, et al. Accumulation of advanced glycation end-products in human dentine. Arch Oral Biol. 2014 Feb;59(2):119-24. https://doi.org/10.1016/i.archoralbio.2013.10.012

31. Vidal CM, Leme AA, Aguiar TR, Phansalkar R, Nam JW, Bisson J, et al. Mimicking the hierarchical functions of dentin collagen cross-links with plant derived phenols and phenolic acids. Langmuir. 2014 Dec;30(49):14887-93. https://doi.org/10.1021/la5034383

32. Liu G, Xu G, Gao Z, Liu Z, Xu J, Wang J, et al. Xu G, Gao Z, Liu Z, Xu J, Wang J, Zhang C, Wang S. Demineralized dentin matrix induces odontoblastic differentiation of dental pulp stem cells. Cells Tissues Organs. 2016;201(1):65-76. https://doi.org/10.1159/000440952

33. Mizutani K, Ikeda K, Kawai Y, Yamori Y. Resveratrol stimulates the proliferation and differentiation of osteoblastic MC3T3-E1 cells. Biochem Biophys Res Commun. 1998 Dec;253(3):859-63. https://doi.org/10.1006/bbrc.1998.9870

34. Ferreira MR, Dernowsek J, Passos GA, Bombonato-Prado KF. Undifferentiated pulp cells and odontoblast-like cells share genes involved in the process of odontogenesis. Arch Oral Biol. 2015 Apr;60(4):593-9. https://doi.org/10.1016/j.archoralbio.2014.09.015 